Received Date : 10-Jul-2012

Accepted Date : 02-Sep-2012

Article type : Primary Research Articles

\title{
Driving factors of a vegetation shift from Scots pine to pubescent oak in dry
}

\section{Alpine forests}

Running title: Drought-induced vegetation shift in Valais

\author{
A. Rigling ${ }^{1}$, C. Bigler ${ }^{2}$, B. Eilmann ${ }^{1,5}$, E. Feldmeyer-Christe ${ }^{1}$, U. Gimmi $^{1}$, C. Ginzler ${ }^{1}$, U. \\ Graf $^{1}$, P. Mayer ${ }^{3}$, G. Vacchiano ${ }^{4}$, P. Weber ${ }^{1}$, T. Wohlgemuth ${ }^{1}$, R. Zweifel ${ }^{1}$, M. Dobbertin ${ }^{1}$ \\ ${ }^{1}$ Swiss Federal Institute for Forest, Snow and Landscape Research, Zurcherstrasse 111, CH- \\ 8903 Birmensdorf, Switzerland \\ ${ }^{2}$ Forest Ecology, Institute of Terrestrial Ecosystems, Department of Environmental Systems \\ Science, ETH Zurich, CH-8092 Zurich, Switzerland \\ ${ }^{3}$ Textflow, Talhofweg 5, CH-8408 Winterthur, Switzerland \\ ${ }^{4}$ Departement of Agronomy, Sylviculture and Land Management, University of Turin, Italy \\ ${ }^{5}$ University \& Research Center Wageningen URL, The Netherlands
}

\section{Corresponding author:}

Andreas Rigling

Swiss Federal Institute for Forest, Snow and Landscape Research

Research Unit Forest Dynamics

Zürcherstrasse 111

CH-8903 Birmensdorf, Switzerland

Tel: ++41447392993

E-mail: andreas.rigling@wsl.ch

Keywords: climate change; land-use change, inner-Alpine dry valleys; Pinus sylvestris; Quercus pubescens; generalized linear models; mixed-effects models

Type of paper: Primary research article

This article has been accepted for publication and undergone full peer review but has not been through the copyediting, typesetting, pagination and proofreading process, which may lead to differences between this version and the Version of Record. Please cite this article as doi: $10.1111 /$ gcb.12038

(C) 2012 Blackwell Publishing Ltd 


\section{Abstract}

An increasing number of studies have reported on forest declines and vegetation shifts triggered by drought. In the Swiss Rhone valley (Valais), one of the driest inner-Alpine regions, the species composition in low-elevation forests is changing: The sub-boreal Scots pine (Pinus sylvestris L.) dominating the dry forests is showing high mortality rates. Concurrently the sub-Mediterranean pubescent oak (Quercus pubescens Willd.) has locally increased in abundance. However, it remains unclear whether this local change in species composition is part of a larger-scale vegetation shift. To study variability in mortality and regeneration in these dry forests we analyzed data from the Swiss National Forest Inventory (NFI) on a regular grid between 1983 and 2003, and combined it with annual mortality data from a monitoring site. Pine mortality was found to be highest at low elevation (below 1000 $\mathrm{m}$ a.s.1.). Annual variation in pine mortality was correlated with a drought index computed for the summer months prior to observed tree death. A generalized linear mixed-effects model indicated for the NFI data increased pine mortality on dryer sites with high stand competition, particularly for small-diameter trees. Pine regeneration was low in comparison to its occurrence in the overstorey, while oak regeneration was comparably abundant. While both species regenerated well at dry sites, pine regeneration was favoured at cooler sites at higher altitude and oak regeneration was more frequent at warmer sites, indicating a higher adaptation potential of oaks under future warming. Our results thus suggest that an extended shift in species composition is actually occuring in the pine forests in the Valais. The main driving factors are found to be climatic variability, particularly drought, and variability in stand structure and topography. Thus, pine forests at low elevations are developing into oak forests with unknown consequences for these ecosystems and their goods and services. 


\section{Introduction}

In recent years an increasing number of studies have reported on forest declines and shifts in species composition in response to changing climatic conditions. Temperature-induced changes include the upward shift of the alpine treeline (Devi et al., 2008; Gehrig-Fasel et al., 2007; Kullman, 2002; Shiyatov, 2003), the poleward shift of the northern tree-line (Esper \& Schweingruber, 2004; Lloyd, 2005), the invasion of evergreen oaks into higher situated mesic broadleaved forests in northeast Spain (Penuelas \& Boada, 2003), the invasion of exotic evergreen broadleaves into mixed temperate broadleaved forests at the southern fringe of the Alps (Walther et al., 2002) and the shift of the upper respectively northern distribution limit of temperature-sensitive plant species such as Viscum album ssp. austriacum (see Dobbertin et al., 2005a).

In addition to temperature-related changes, drought has also been identified as an important trigger for forest decline and decline-induced vegetation shifts (Allen \& Breshears, 1998; Breshears et al., 2005; Penuelas \& Boada, 2003). A global overview on drought-induced forest decline was recently presented in Allen et al. (2010). Drought may directly cause mortality via hydraulic failure in extreme drought events (Bréda et al., 2006; McDowell et al., 2008), or indirectly, as a persistent weakening of trees by reducing carbon storage (Eilmann et al., 2010; McDowell et al., 2008). Therefore, these weakened trees are increasingly vulnerable to additional stressors like insects (Rouault et al., 2006; Wermelinger et al., 2008), fungi (Heiniger et al., 2011; Giordano et al., 2009), nematodes (Polomski et al., 2006), and mistletoes (Dobbertin and Rigling, 2006; Rigling et al., 2010; Zweifel et al., 2012).

Drought is also a limiting factor in forest ecosystems in inner-Alpine valleys such as the Valais, Switzerland. Scots pine (Pinus sylvestris L.) dominates forest stands in the driest parts of the valley, i.e. from 700 to 1100 m a.s.l., but recently high mortality rates of Scots pine have been observed in this region (Bigler et al., 2006; Dobbertin et al., 2005b) and in other 
inner-Alpine valleys with similar climatic conditions such as the Italian Aosta valley (Vertui \& Tagliaferro, 1998; Vacchiano et al., 2011), or the Austrian Inn valley (Oberhuber, 2001). Concurrently, deciduous tree species, in particular pubescent oak (Quercus pubescens Willd.) are becoming locally more abundant and are increasingly competing with Scots pine on dry sites (Weber et al., 2007, 2008a). The question arises whether these observed changes indicate a general shift in species composition or whether these changes are restricted to a few extreme sites only.

The Valais is among the driest inner valleys of the European Alps (Braun-Blanquet, 1961; Ozenda, 1985). On south-facing slopes with shallow soils Scots pine forests give way to steppe-like vegetation. On these sites a change in climate conditions is expected to have a strong effect on tree growth and tree survival as well as on the persistence of forest cover (Moser et al., 2010). Regional climatic conditions significantly changed within the last 100 years. Whereas the precipitation regime was relatively constant (Begert et al., 2005), the increase in temperature (Begert et al., 2005) and frequency of hot days during the summer months (Rebetez \& Dobbertin, 2004) intensified the evapotranspiration and led to increasing drought stress for the plants, particularly in dry years when water is limited (Rebetez \& Dobbertin, 2004). This aggravation of water shortage is expected to have a strong impact on tree survival and regeneration.

At dry sites Scots pine and pubescent oak are competing for the same resources. Scots pine is a sub-boreal species with a wide distribution range, however in the Valais, Scots pine is growing close to the southern distribution limit where it locally reaches its dry limits at lower elevations (Boratynski, 1991; Meusel, 1992). At lower latitudes Scots pine occurrence is restricted to higher altitudes only (Boratynski, 1991). In contrast, pubescent oak has a subMediterranean origin with a much smaller distribution range (Meusel, 1992). In the Valais pubescent oak grows close to its northern distribution limit. Hence, both species must be 
considered as highly sensitive to direct and indirect effects of the ongoing and expected future climate changes (Zweifel et al., 2009) and the question arises whether pubescent oak will replace or displace upward Scots pine in the Valais, when considering the tree-specific physiological capabilities (Zweifel et al., 2006, 2007, 2009).

The aim of this study was to analyze the dynamics of the Scots pine forests in the Valais during two decades with respect to driving factors leading to these changes. We focused on the spatial and temporal changes in forest structure, species composition, tree mortality, and tree regeneration. Because of the varying spatial and temporal dimensions of the forest changes two approaches differing in scale (space and time) and methodology were combined: Firstly, we resampled the Swiss National Forest Inventory (NFI) on the regular $1 \times 1 \mathrm{~km}$ grid in the Valais, consisting of 201 grid points between the valley bottom at $430-700 \mathrm{~m}$ a.s.1. and 1600 m a.s.l. At each grid point 20-year mortality (1983/85 to 2002/03) of Scots pine was analyzed and the actual state of tree regeneration in 2002/03 was surveyed and related to climate and site parameters. Secondly, tree mortality from a long-term experimental site at Visp and climate data with high temporal resolution were interrelated.

The following questions were addressed: 1) Is the shift from Scots pine to pubescent oak a general pattern in the Valais or is it restricted to extreme sites only? 2) What factors impact tree mortality and regeneration of the two species?

\section{Material and Methods}

\section{Study area}

The Swiss Rhone valley is an inner-Alpine dry valley (Fig. 1). The surrounding mountain ranges, with altitudes exceeding $4000 \mathrm{~m}$, shelter the inner part of the valley from the moist oceanic air masses transported with westerly and southerly winds. As a result a steep precipitation gradient exists with yearly precipitation of $1046 \mathrm{~mm}$ in Bex in the west to 871 
$\mathrm{mm}$ in Martigny and $599 \mathrm{~mm}$ in Sion and Visp in the central and eastern part of the Valais (period 1961-1990, MeteoSwiss). In addition there is also a gradient in the seasonal distribution of precipitation: from the west with a distinct maximum of precipitation in summer to the central area of the valley with an even distribution of precipitation over the year (Fig. 1). Drought years with yearly precipitation below $500 \mathrm{~mm}$ are frequent in central Valais (20 drought years occurred in the last century in Visp). Cloudiness is generally very low and, as a consequence, solar radiation is high. Mean annual temperature in Sion is $9.2^{\circ} \mathrm{C}$ (norm period 1961-1990, MeteoSwiss). The steep climatic gradient is well reflected by the forest composition: European beech (Fagus sylvatica), an indicator species of the temperate deciduous forests (Mayer, 1984; Ozenda, 1985), tends to dominate forests in the atlantic western part but lacks in the drier central part of the main valley, where more droughtresistant pine and oak forests at lower elevations and various coniferous forests from $1000 \mathrm{~m}$ a.s.1. to the treeline dominate (Brändli, 2010).

\section{Inventory data and description of predictor variables}

Swiss forests are inventoried every decade on a grid of permanent plots (Bachofen \& Mahrer, 1988; Brändli, 2010; Brassel \& Brändli, 1999). The first Swiss National Forest Inventory was conducted from 1983 to 1985 on a regular $1 \times 1 \mathrm{~km}$ grid. From 1993 to 1995 the inventory was repeated on half of the original plots with a random selection of plots on an additional $0.5 \times 0.5$ $\mathrm{km}$ grid. To study recent changes in the Scots pine forests of the Valais, existing NFI plots served to reassess the presence and state of trees and document natural tree regeneration in 2002 and 2003 . For this purpose 201 plots (186 plots on the $1 \times 1 \mathrm{~km}$ grid plus 15 plots on the $0.5 \times 0.5 \mathrm{~km}$ grid) were selected up to the approximate limit of Scots pine dominance at about 1600 m a.s.1. (Fig. 2). 
Each plot consists of two concentric circles. In the $200 \mathrm{~m}^{2}$ circle all overstorey trees with $\geq 12$ $\mathrm{cm}$ stem diameter at breast height $(\mathrm{DBH})$ and in the $500 \mathrm{~m}^{2}$ circle all trees with $\geq 36 \mathrm{~cm}$ DBH were monitored. Any mortality and abundance data that were used in the analyses and presented in the results were based on weighted data, i.e. trees from the $200 \mathrm{~m}^{2}$ circle were weighted with 2.5 , trees from the $500 \mathrm{~m}^{2}$ circle were weighted with 1.0 . For the 186 plots on the $1 \times 1 \mathrm{~km}$ grid we reported tree mortality and removal rates for the period from $1983 / 85$ to 2002/2003, while all plots assessed in 2002/2003 (i.e. including 15 plots on the $0.5 \times 0.5 \mathrm{~km}$ grid) were used for comparison of the current forest structure and species composition. For trees that were cut between the two inventories we were not able to distinguish between regular management operations or salvage cuttings. Hence, we computed both tree mortality and the combined value of tree mortality and removal.

In order to assess the recruitment of Scots pine and pubescent oak we counted all saplings smaller than $20 \mathrm{~cm}$ height on a $50 \mathrm{~m}^{2}$ circle on each grid plot. Canopy cover was estimated visually and was used as a surrogate for light availability for tree regeneration. Furthermore, we estimated the percentage cover of bare soil versus soil with organic layers to characterize the seed-bed of the saplings. Browsing damage on buds and shoots was assessed for each sapling.

For each plot, we derived additional variables that were related to climate variability, stand structure and topography. Climate variability was represented by a drought index and degree days. A monthly drought index as an estimate for water availability was calculated as the difference between monthly precipitation sum $(\mathrm{P})$ and potential evapotranspiration (PET) according to Turc (1963). Degree days were calculated as the sum of mean daily temperatures above $5^{\circ} \mathrm{C}$. Annual values for the long-term period 1961-1990 were computed for all climate variables. All climatic data obtained from the climate stations of MeteoSwiss were interpolated for the inventory plots using an inverse weighted distance approach 
(Zimmermann \& Kienast, 1999). Stand structure was characterized by stand basal area calculated over all species for all trees that were alive in $1983 / 85$. Topography was represented by aspect (north, south, east, west), slope steepness and elevation.

\section{Modelling tree mortality and tree regeneration}

For Scots pine, we quantified the effects of climate, stand structure and topography on individual-tree mortality (i.e. including dead and removed trees) between 1983/85 and $2002 / 03$. Only Scots pine were considered that were alive in $1983 / 85$. Generalized linear mixed-effects models (GLMMs) were fitted with a binomial distribution (Pinheiro \& Bates, 2000; Zuur et al., 2009) defined by the density function:

$f(y ; p)=\left(\begin{array}{c}N \\ y\end{array}\right) \times p^{y} \times(1-p)^{N-y}$

where $\mathrm{N}$ is the number of dead and living trees and $\mathrm{y}$ the number of living trees. The survival probability $\mathrm{p}$ of a tree is modelled with the logit link function:

$\ln \left(\frac{p}{1-p}\right)=X \beta$

where $\ln$ is the natural $\log , \mathrm{X}$ is a matrix that contains the predictor variables and $\beta$ is a vector with the regression coefficients. To estimate model parameters the "Imer" function of the "Ime4" package (version 0.999375-40) in the statistical computing software R (version 2.12.0; R Development Core Team, 2010) was used. Combinations of the following predictor variables were included as fixed effects in the models: drought index, degree days, aspect, slope steepness, stand basal area and DBH (as measured in 1983/85). To reduce numerical instabilities and increase convergence in the model fitting process, the variable degree days was divided by 10. Elevation was not considered in the models because of the high correlation with the two climate variables. To take into account plot-to-plot variability, the intercept was 
included as random effect. After removing observations with missing values, the dataset was reduced from 1014 Scots pine in 139 plots to a total of 985 Scots pine in 137 plots, which were included in the mortality models. A weight argument in the model formulation allowed to consider whether a tree was observed in the $200 \mathrm{~m}^{2}$ or $500 \mathrm{~m}^{2}$ circle without inflating the number of observations.

For both Scots pine and pubescent oak, the effects of climate, topography, canopy cover and bare soil on tree regeneration as determined in 2002/03 were quantified. These count data were modelled with generalized linear models using a negative binomial distribution (Zuur et al., 2009; Van der Burght et al., 2012) defined by the density function:

$f(y ; \theta, \mu)=\frac{\Gamma(\theta+y)}{\Gamma(\theta) \times y !} \times \frac{\mu^{y} \theta^{\theta}}{(\mu+\theta)^{\theta+y}}$

where $y$ is the number of regeneration, $\Gamma$ is the gamma distribution and $\theta$ the dispersion parameter taking into account overdispersion (i.e. the variance is greater than the mean; Zuur et al., 2009). The mean $\mu$ is modelled with the log-link function:

$\ln (\mu)=X \beta$

where $\mathrm{X}$ is a matrix with the predictor variables and $\beta$ is a vector with the regression coefficients. The "glm.nb" function of the "MASS" package (version 7.3-8) in the statistical computing software R (R Development Core Team, 2010) was used to fit the models. The following predictor variables were combined in the models: drought index, degree days, aspect, slope steepness, canopy cover and bare soil. After removing observations with missing values, the dataset was reduced for both Scots pine and pubescent oak from 201 to 193 plots, which were included in the regeneration models.

For both the mortality models and regeneration models, we followed an information-theoretic model selection approach based on the $\mathrm{AIC}_{\mathrm{c}}$ (corrected Akaike Information Criterion; Burnham \& Anderson, 2002; Stauffer, 2008). In both cases, we defined a priori 14 models 
using different combinations of predictor variables (Appendix Tab. A, B and C). The models were ranked according to the $\mathrm{AIC}_{\mathrm{c}}$, i.e. the model with the lowest $\mathrm{AIC}_{\mathrm{c}}$ was considered to be the best-fitting model within each selection of 14 models. For each model, we calculated the Akaike weight (Burnham \& Anderson, 2002), which is the probability that a specific model is the best-fitting model within these 14 models.

\section{Long-term monitoring at research plot}

Annual variation in Scots pine mortality was studied based on data from a research plot established in 1996 close to the community of Visp (Fig. 1). The plot belongs to the Swiss Long-term Forest Research network, which is part of the European level II monitoring network of ICP Forests (Lorenz, 1995). In this 2 ha plot all trees were geo-referenced and tree sizes were measured. Each August between 1996 and 2011, mortality of every single Scots pine was assessed (Dobbertin \& Rigling, 2006). The MeteoSwiss climate station Visp is located in $2 \mathrm{~km}$ distance from the plot.

\section{Results}

Presence of Scots pine and pubescent oak in the overstorey

A total of 2010 living Scots pines $\geq 12 \mathrm{~cm} \mathrm{DBH} \mathrm{(200.0} \mathrm{trees} \mathrm{per} \mathrm{ha)} \mathrm{was} \mathrm{found} \mathrm{on} 153$ out of the 201 plots in 2003, whereas living pubescent oaks in the overstorey were only present on 19 plots with an estimated total of 114 individuals (11.3 trees per ha; Tab. 1). For both species there were no distinct longitudinal-latitudinal trends in species distribution (Fig. 2). In contrast the altitudinal distribution differed. Scots pine was evenly distributed within the studied sites (up to $1600 \mathrm{~m}$ a.s.l.), whereas pubescent oak peaked at 800 to $1000 \mathrm{~m}$ a.s.l. and was rarely found above $1200 \mathrm{~m}$ a.s.l. (Fig. 2). 
The survey of 1983/85 (Tab. 1) accounted for 139 plots with 2254 Scots pines (242.3 trees per ha) and 11 plots with 41 pubescent oaks (4.4 trees per ha) in the overstorey. Compared to the survey in 1983/85 the abundance of pubescent oak increased in the overstorey until 2002/03 by $160.7 \%$ in contrast to the decreasing abundance of Scots pine $(-17.5 \%)$.

\section{Tree mortality}

Within the two decades of investigation a total of 33.2 Scots pines and 0.4 pubescent oaks died per ha (Tab. 1). The percentage of mortality was almost $60 \%$ higher in Scots pine $(13.7 \%)$ than in pubescent oak $(8.6 \%)$. The 20 -yr rate for mortality and removal was more than twice as high for Scots pine (32.5\%) than for pubescent oak (14.8\%). A majority of the dead and removed Scots pines were observed in the interior part of the Valais. Mean rates of mortality and removal increased with decreasing altitude, however variability at altitudes $\leq$ $600 \mathrm{~m}$ was high (Fig. 3). In altitudes below $1000 \mathrm{~m}$ a.s.l., Scots pine mortality was about twice the mean mortality in Switzerland (0.3-0.5\% per year). The mean rate of mortality and removal in low altitude was four times higher than the nationwide average mortality (Fig. 3). Due to small absolute numbers, oak mortality was not further analysed.

The mortality model SMP10 (Tab. 2, Appendix Table A) had a probability of $45 \%$ to be the best-fitting model among the 14 models explaining survival probabilities of Scots pine. The model included the predictor variables drought index (P-PET, positive correlation with survival probabilities), stand basal area in 1983 (negative correlation) and DBH in 1983 (positive correlation). Hence mortality in Scots pine was increased at drier sites, in stands with high stand basal area and in trees with small DBH.

The data from the long-term monitoring plot at Visp showed a negative correlation between summer drought (drought index, April-August) and Scots pine mortality, which was assessed 
in the following summer (end of July to beginning of August) (Spearman rank correlation between drought index and subsequent annual mortality rate: $-0.72, \mathrm{p}<0.01$, Fig. 4).

\section{Tree regeneration}

The spatial distribution of tree regeneration $(0-20 \mathrm{~cm}$; Fig. 2) differed between the two species: Scots pine saplings were only found in the central and western part of the Valais. In the eastern part, the driest area, Scots pine regeneration was basically absent. Pubescent oak saplings were almost evenly distributed over the entire valley with a maximum in abundance in the western and central parts.

Scots pine saplings were found on 34 out of 201 plots whereas pubescent oak regeneration occurred on nearly twice as many plots (67 plots, Tab. 3). Five times more pubescent oak saplings ( $n=2343 ; 2331.3$ saplings per ha) were recorded than Scots pine saplings $(n=486$; 483.6 saplings per ha). When comparing regeneration at the plot level, more saplings were found for pubescent oak than for Scots pine $(\mathrm{P}=0.00052$; paired Wilcoxon signed rank test $)$. In only $20 \%$ of the plots with Scots pine in the overstorey saplings of the species were observed. In contrast, on $74 \%$ of the plots with pubescent oak overstorey also oak saplings occurred. In plots without the two tree species in the overstorey, saplings of Scots pine and oak were found in $8 \%$ and $79 \%$ of the plots, respectively.

For Scots pine the number of regeneration was best modelled with model RMP07, which had a probability of $52 \%$ to be the best-fitting model among the 14 models. The model included the predictor variables drought index and degree days, both were negatively correlated with regeneration (Tab. 4; Appendix Tab. B). For pubescent oak the best fit showed model RM012 with a probability of $84 \%$ (Tab. 4; Appendix Tab. C), which was based on the explaining variable drought index (negative correlation) and the positively correlated variables degree

days, aspect and slope steepness. Hence regeneration of both species was more frequent on 
drier sites. Scots pine was more frequent on cooler sites (i.e. higher altitudes) whereas oak was more successful at warmer sites (i.e. sites at lower altitudes). In addition oak regeneration was more frequent on steep slopes that were facing east, south or west. Canopy cover (negative correlation) and bare soil (positive correlation) were included in the second bestfitting model for Scots pine (Appendix Tab. C).

On average, deciduous tree species were browsed two to four times more often (12-22\%) than conifers (5-10\%, see Fig. 5). Browsing pressure was lowest for saplings of Scots pine, common juniper (Juniperus communis) and shrubs with thorns (5 - 7\% of the saplings were browsed). The highest pressure was on saplings of maple (Acer sp.), common whitebeam (Sorbus aria) and shrubs without thorns (18 - 21\% of the saplings were browsed). In pubescent oak $16 \%$ of the saplings were browsed.

\section{Discussion}

\section{Driving factors of tree mortality}

The combined results of the two approaches using datasets, which differ in their spatial coverage (grid analysis versus long-term monitoring plot) and temporal resolution (decadal versus yearly), revealed the importance of the joint effects of drought, stand structure and tree size on the observed Scots pine decline in inner-Alpine forests. Scots pine mortality was increased on dry plots with high stand competition as represented by stand basal area (Tab. 2) particularly following dry years (Fig. 4) and for small-diameter trees (Tab. 2). High stand competition implies increased water consumption, hence in this dry environment drought stress is increased in denser stands (Weber et al., 2007, 2008a). This coincides with a study by Oberhuber (2001) of a Scots pine stand near Innsbruck (Austria), where the highest mortality rates occurred on the most drought exposed sites. Our data showed for the dryer sites below $1000 \mathrm{~m}$ a.s.l. almost three times higher mortality rates compared to the mean mortality of 
Scots pine nationwide, and even four times higher rates when including tree removal. At low elevations most pine forests have little economic value due to slow tree growth and poor stem quality. As a consequence these forests have never been regularly managed (Gimmi et al., 2010) and therefore, most cutting operations likely occurred to remove dead trees. If these removed trees are not added to the mortality data, pine mortality is rather underestimated at lower altitudes. Actual mortality was probably close to the estimated values of mortality including tree removal. However, at high elevations timber quality is improved and regular cuttings for economic reasons are practiced. Thus above $1000 \mathrm{~m}$ a.s.l., the actual Scots pine mortality might be well described with our observed mortality data only (without tree removal).

The sub-Mediterranean pubescent oak seems to cope better with severe drought than Scots pine resulting in lower mortality rates (Tab. 1). This might be explained by the ability of pubescent oak for long-lasting stomata opening under drought compared to Scots pine (Zweifel et al., 2005, 2006, 2009) resulting in higher photosynthetic activity. However, during the summer heat wave 2003, also pubescent oak reached its physiological limits and showed a complete leaf shedding already in July (Zweifel et al., 2006). Both Scots pine and pubescent oak completely ceased their assimilation during that period (Zweifel et al., 2009), which might be the reason for the drastic growth depression in Scots pine (Eilmann et al., 2011; Oberhuber et al., 1998; Rigling et al., 2001, 2002, 2003) but also in pubescent oak during extreme dry years (Eilmann et al., 2006, 2009; Weber et al., 2007).

Repeated drought might lead to progressive depletion of stored carbohydrates because freshly produced assimilates cannot cover carbon needs for the trees' metabolism, defense and growth (Bréda et al., 2006; McDowell et al., 2008). Whereas carbon starvation was identified as a relevant process in Scots pine decline in northeast Spain (Galiano et al., 2011) and in the Valais (Eilmann et al., 2010), Gruber et al. (2012) and Oberhuber et al. (2011) could not 
show any reductions in carbon reserves of Scots pines in a dry year nor on a dry site near Innsbruck (Austria). Beside carbon starvation hydraulic failure is another limiting process weakening trees during drought (McDowell et al., 2008, 2011) and increasing the trees' vulnerability against additional stressors such as i) the semi-parasite pine mistletoe (Viscum album ssp. austriacum) aggravating the drought stress of the host tree (Dobbertin \& Rigling, 2006; Rigling et al., 2010), or ii) pests and insects (Braasch \& Enzian, 2004; Dobbertin et al., 2007; Polomski et al., 2006; Wermelinger et al., 2008). These attacks by additional stressors might gain importance because increasing warming is expected to speed up insect reproduction and development, which finally might increase the infestation pressure (e.g. Bale et al., 2002; Gan, 2004; Wermelinger \& Seifert, 1999).

\section{Occurrence and ecology of tree regeneration}

Even though Scots pine dominates the overstorey its recruitment is generally poor (Fig. 2;

Tab. 3). In stands without dominant Scots pine, its regeneration was essentially absent.

Pubescent oak shows an opposite pattern with still relatively few trees in the overstorey but a large sapling bank, even in stands without seed trees. This situation is remarkable considering the reproductive strategy of the two species (e.g. Bran et al., 1990; Keeley \& Zedler, 1998; Lanner, 1998) with Scots pine producing a high amount of light and winged seed, which easily disperse, whereas pubescent oak produces relatively few and heavy seeds, which are dispersed by animals. Based on these differing strategies one would expect Scots pine predominantly colonizing new areas, which was obviously not the case in recent years in the Valais. A potential bottleneck for Scots pine recruitment, particularly for germination and establishment, are dry and warm springs as shown by Moser et al. (2010) for tree regeneration after a stand replacing fire. Obviously, current site conditions seem to be less favourable for Scots pine than for pubescent oak regeneration (Gimmi et al., 2010). Furthermore, pubescent 
oak regeneration will increase in the near future due to the increasing in-growth in the overstorey and subsequent increasing numbers of seed trees (cf. Table 1).

Both species regenerated more frequently with increasing dryness of the site. This is likely caused by increased competition by less drought tolerant tree species on moister sites.

Although Scots pine and pubescent oak recruitment were both more frequent on dry sites, significant differences exist between the two species (Tab. 4): Scots pine regeneration was favoured on cooler sites at higher altitudes (negative correlation with degree days), whereas pubescent oak was more frequent on warmer sites at lower altitudes (positive correlation with degree days) at west-, east- and south-facing aspects, which tend to be warmer and dryer compared to north-facing aspects. This is in accordance with the results of Moser et al. (2010) on a nearby study site demonstrating that post-fire Scots pine regeneration success was hindered on warm-dry sites at low altitudes, whereas broadleaved pioneer tree species were able to establish on the driest sites. These findings fully correspond with studies from Spain showing for Scots pine regeneration drought as a main mortality factor (Castro et al., 2005) and a reduced post-fire regeneration success (Vila-Cabrera et al., 2012). The lower abundance of pubescent oak saplings at higher altitudes might also be caused by its high sensitivity to late frost (Thomas et al., 2002). In addition pubescent oak was slightly more frequent on steep slopes (positive correlation), which often feature higher run-off and generally more shallow soils.

In contrast to studies from southern Spain, where establishment of Scots pine seedlings was reduced under the canopy of Scots pine and increased on bare soils (Castro et al., 2004), these two factors turned out to be less important in the Valais (Appendix Tab. B).

Beside site conditions, browsing by domestic animals and game is another important limitation for tree regeneration (e.g. Zamora et al., 2001). Our results showed that the current browsing pressure on Scots pine is relatively low in the Valais (Fig. 5), which is probably due 
to the high availability of more attractive broadleaves and shrubs. Thus, Scots pine regeneration in the Valais was hindered less by grazing compared to degraded Mediterranean forests with predominantly thorny shrubs where Scots pine seedlings are generally more frequently browsed (e.g. Gomez et al., 2001; Hodar et al., 1998). By contrast, pubescent oak is more attractive for browsing compared to Scots pine (Fig. 5). Hence, browsing cannot explain the differences in sapling occurrence between Scots pine and pubescent oak. However, previous land-use practices might partly explain the more abundant regeneration of pubescent oak, since past forest management including intensive forest pasture (browsing) and litter raking (seed removal) created environmental conditions, which hindered regeneration of deciduous trees (Gimmi et al., 2010; Weber et al. 2008b). Thus, the abandonment of these practices had a positive effect on the regeneration of pubescent oak as reflected by its current expansion (Fig. 2, Tab. 3).

\section{Vegetation shift}

Our results of the forest inventory definitely demonstrate that Scots pine is still dominating on the landscape scale at the dry low elevation sites, while pubescent oak is generally not yet abundant in the overstorey and basically absent above $1200 \mathrm{~m}$ a.s.l. (Fig. 2 and 3). But changes in land-use practices will generally result in an increase of oak regeneration, and future climatic changes might result in more frequent drought (Schaer et al., 2004) and subsequent increased Scots pine mortality. Hence in the long run the Scots pine forests at lower altitudes are likely to develop towards pubescent oak forests (Gimmi et al., 2010).

In particular in the region of Visp the proposed vegetation shift is already well advanced: A century ago the forests consisted essentially only of Scots pine with some pubescent oakshrubs outside the closed forest (Christ, 1920; Schmid, 1936). In contrast, pubescent oak and 
other broadleaves are currently dominating the forests below approximately $1000 \mathrm{~m}$ a.s.l. where only a few Scots pines have remained (Gimmi et al., 2010).

The findings of our study demonstrate that there is a significant change going on in forest vegetation below $1000 \mathrm{~m}$ a.s.l. in the Valais. In other inner-Alpine Scots pine forests in Switzerland (Schilli et al., 2008), Italy (Minerbi, 1993; Vertui \& Tagliaferro, 1998), France (Thabeet et al., 2009), and Austria (Cech \& Perny, 2000; Cech \& Wiesinger, 1995; Oberhuber, 2001) similar mortality processes have been reported or are currently progressing. Thus, we assume that the conditions analyzed in the Valais are representative for many of the dry inner-Alpine valleys. But also outside the Alps drought-induced vegetation shifts were reported e.g. for northern Spain (Lloret et al., 2004; Penuelas \& Filella, 2001), the Pyrenees (Galiano et al., 2010) or for several regions in the United States, (Allen \& Breshears, 1998; Breshears et al., 2005; Kelly \& Goulden, 2008; Mueller et al., 2005; van Mantgem et al., 2009) and might gain in importance due to climate change (IPCC, 2007).

In conclusion, we revealed evidence of a vegetation shift in the Valais caused by increasing mortality after drought periods, a general decrease of Scots pine regeneration and an increasing regeneration success of pubescent oak. Hence this is a clear indication that the vegetation shift was driven by both climate variability, with Scots pine mortality being affected by water shortage, and land-use change with increased stand competition aggravating the drought stress for Scots pine and with a stimulation of pubescent oak regeneration (Gimmi et al., 2010).

Pubescent oak copes well with dry and warm conditions, and neither increased mortality rates nor a limitation of recruitment in response to drought have been observed so far. Since pubescent oak is currently dominating the sapling bank in these dry forests in the Valais, the change from Scots pine forests to pubescent oak dominated forests seems to be inevitable at 
low elevations. However, there are indications that even the drought-tolerant pubescent oak may reach the limits of its physiological capacity in a drier future climate (Eilmann et al., 2009). In addition, the extensive expansion of pubescent oak might generally increase the risk of species-specific biotic pests (Bale et al., 2002). Hence, the long-term dynamics of these dry inner-Alpine forests remains open and so are the consequences for the concerned forest goods and services (Rigling et al., 2012).

\section{Acknowledgement}

We wish to thank our field teams Raphael Siegrist, Fredy Potzinger, Nadine Hilker, Tilo Usbeck, Christophe Praz and Fabienne Zeugin. The study was funded by the research programme "Forest Dynamics" of the Swiss Federal Research Institute for Forest, Snow and Landscape WSL, the Canton of Valais, the Federal Office for the Environment FOEN and the Interreg III. The study was supported by the project MOUNTLAND of the Competence Center for Environment and Sustainability of the ETH-Domain Switzerland. We are grateful to Konrad Egger and Alban Brigger from the forest service of Valais for fruitful discussions and technical support. This study is dedicated to the memory of our friend and colleague Giovanni Nicolotti who tragically passed away before our joint research projects were completed.

\section{References}

Allen CD, Breshears DD (1998) Drought-induced shift of a forest-woodland ecotone: Rapid landscape response to climate variation. Proceedings of the National Academy of Sciences of the United States of America, 95, 14839-14842.

Allen CD, Macalady AK, Chenchouni $\mathrm{H}$ et al. (2010) A global overview of drought and heatinduced tree mortality reveals emerging climate change risks for forests. Forest Ecology and Management 259, 660-684.

Bachofen H, Mahrer F (1988) Schweizerisches Landesforstinventar Ergebnisse der Erstaufnahme 1982-1986, Teufen, Kommissionsverlag Flück-Wirth. 
Bale JS, Masters GJ, Hodkinson ID et al. (2002) Herbivory in global climate change research: direct effects of rising temperature on insect herbivores. Global Change Biology, 8, 116.

Begert M, Schlegel T, Kirchhofer W (2005) Homogeneous temperature and precipitation series of Switzerland from 1864 to 2000. International Journal of Climatology, 25, 65-80.

Bigler C, Bräker OU, Bugmann H, Dobbertin M, Rigling A (2006) Drought as an inciting mortality factor in Scots pine stands of the Valais, Switzerland. Ecosystems, 9, 330343.

Boratynski A (1991) Range of natural distribution. In: Genetics of Scots pine. (eds Giertych M, Matyas C) pp 19-30. Elsevier.

Braasch H, Enzian S (2004) The pine wood nematode problem in Europe - present situation and outlook. Pinewood Nematode, Bursaphelenchus Xylophilus, 1, 77-91.

Bran D, Lobreaux O, Maistre M, Perret P, Romane F (1990) Germination of Quercus ilex and Quercus pubescens in a Quercus ilex coppice - long-term consequences. Vegetatio, 87, 45-50.

Brändli U-B (2010) Schweizerisches Landesforstinventar. Ergebnisse der dritten Erhebung 2004-2006, Birmensdorf, Eidgenössische Forschungsanstalt für Wald, Schnee und Landschaft (Birmensdorf).

Brassel P, Brändli U-B (1999) Schweizerisches Landesforstinventar. Ergebnisse der Zweitaufnahme 1993 - 1995, Bern [etc.], Haupt.

Braun-Blanquet J (1961) Die inneralpine Trockenvegetation, Stuttgart, Fischer Verlag.

Bréda N, Huc R, Granier A, Dreyer E (2006) Temperate forest trees and stands under severe drought: a review of ecophysiological responses, adaptation processes and long-term consequences. Annals of Forest Science, 63, 625-644.

Breshears DD, Cobb NS, Rich PM et al. (2005) Regional vegetation die-off in response to global-change-type drought. Proceedings of the National Academy of Sciences of the United States of America, 102, 15144-15148.

Burnham KP, Anderson DR (2002) Model selection and multimodel inference: a practical information-theoretic approach. 2nd edition. Springer, New York.

Castro J, Zamora R, Hodar JA, Gomez JM (2004) Seedling establishment of a boreal tree species (Pinus sylvestris) at its southernmost distribution limit: consequences of being in a marginal Mediterranean habitat. Journal of Ecology, 92, 266-277.

Castro J, Zamora R, Hodar JA, Gomez JM (2005) Alleviation of summer drought boosts establishment success of Pinus sylvestris in a Mediterranean mountain: an experimental approach. Plant Ecology, 181, 191-202.

Cech T, Perny B (2000) Kiefernsterben im Tirol. Forstschutz aktuell, 22, 12-15.

Cech TL, Wiesinger R (1995) Kiefernsterben in Niederösterreich. In: Österreichisches Waldschaden-Beobachtungssystem. (ed Neumann M) Wien, Bericht Forstliche Bundesversuchsanstalten.

Christ P (1920) Geologische Beschreibung des Klippengebietes Stanserhorn-Arvigrat am Vierwaldstättersee. Basel Phil Diss, Buchdr. Stämpfli \& Cie, Bern, 64 pp.

Devi N, Hagedorn F, Moiseev P, Bugmann H, Shiyatov S, Mazepa V, Rigling A (2008) Expanding forests and changing growth forms of Siberian larch at the Polar Urals treeline during the 20th century. Global Change Biology, 14, 1581-1591.

Dobbertin M, Hilker N, Rebetez M, Zimmermann NE, Wohlgemuth T, Rigling A (2005a) The upward shift in altitude of pine mistletoe (Viscum album ssp austriacum) in Switzerland - the result of climate warming? International Journal of Biometeorology, 50, 40-47. 
Dobbertin M, Mayer P, Wohlgemuth T, Feldmeyer-Christe E, Graf U, Zimmermann NE, Rigling A (2005b) The decline of Pinus sylvestris L. forests in the Swiss Rhone valley - a result of drought stress? Phyton 45, 153-156.

Dobbertin M, Rigling A (2006) Pine mistletoe (Viscum album ssp austriacum) contributes to Scots pine (Pinus sylvestris) mortality in the Rhone valley of Switzerland. Forest Pathology, 36, 309-322.

Dobbertin M, Wermelinger B, Bigler C et al. (2007) Linking increasing drought stress to Scots pine mortality and bark beetle infestations. The Scientific World Journal, 7, 231239.

Eilmann B, Buchmann N, Siegwolf R, Saurer M, Cherubini P, Rigling A (2010) Fast response of Scots pine to improved water availability reflected in tree-ring width and 13C. Plant Cell and Environment, 33,1351-1360.

Eilmann B, Weber P, Rigling A, Eckstein D (2006) Growth reactions of Pinus sylvestris L. and Quercus pubescens Willd. to drought years at a xeric site in Valais, Switzerland. Dendrochronologia, 23, 121-132.

Eilmann B, Zweifel R, Buchmann N, Fonti P, Rigling A (2009) Drought-induced adaptation of the xylem in Scots pine and pubescent oak. Tree physiology, 29, 1011-1020.

Eilmann B, Zweifel R, Buchmann N, Graf-Pannatier E, Rigling A (2011) Drought alters timing, quantity, and quality of wood formation in Scots pine. Journal of Experimental Botany, 62, 2763-2771.

Esper J, Schweingruber FH (2004) Large-scale treeline changes recorded in Siberia. Geophysical Research Letters, 31, 1-5.

Galiano L, Martinez-Vilalta J, Lloret F (2010) Drought-induced multifactor decline of Scots pine in the Pyrenees and potential vegetation change by the expansion of co-occuring oak species. Ecosystems, 13, 978-991.

Galiano L, Martinez-Vilalta J, Lloret F (2011) Carbon reserves and canopy defoliation determine the recovery of Scots pine $4 \mathrm{yr}$ after a drought episode. New Phytologist, 190, 750-759.

Gan JB (2004) Risk and damage of southern pine beetle outbreaks under global climate change. Forest Ecology and Management, 191, 61-71.

Gehrig-Fasel J, Guisan A, Zimmermann NE (2007) Tree line shifts in the Swiss Alps: Climate change or land abandonment? Journal of Vegetation Science, 18, 571-582.

Gimmi U, Wohlgemuth T, Rigling A, Hoffmann CW, Burgi M (2010) Land-use and climate change effects in forest compositional trajectories in a dry Central-Alpine valley. Annals of Forest Science, DOI: 10.1051/forest/2010026.

Giordano L, Gonthier P, Varese GC, Miserere L, Nicolotti G (2009) Mycobiota inhabiting sapwood of healthy and declining Scots pine (Pinus sylvestris L.) trees in the Alps. Fungal Diversity, 38, 69-83.

Gomez JM, Hodar JA, Zamora R, Castro J, Garcia D (2001) Ungulate damage on Scots pines in Mediterranean environments: effects of association with shrubs. Canadian Journal of Botany-Revue Canadienne De Botanique, 79, 739-746.

Gruber A, Pirkebner D, Florian C, Oberhuber W (2012) No evidence for depletion of carbohydrate pools in Scots pine (Pinus sylvestris L.) under drought stress, Plant Biology, 14, 142-148.

Heiniger U, Theile F, Rigling A, Rigling D (2011) Blue-stain infections in roots, stems and branches of declining Pinus sylvestris in a dry inner alpine valley of Switzerland. Forest Pathology, 41, 501-509.

Hodar JA, Castro J, Gomez JM, Garcia D, Zamora R (1998) Effects of herbivory on growth and survival of seedlings and saplings of Pinus sylvestris nevadensis in SE Spain. In: 
Ecological basis of livestock grazing in Mediterranean ecosystems. (eds Papanastasis VP, Peters D) pp 264-267. Luxembourg, European Union.

IPCC (2007) Technical report. In: Climate Change 2007: The Physical Science Basis. Contribution of Working Group I to the Fourth Assessment Report of the Intergovernmental Panel on Climate Change. (ed Solomon S, D. Qin, M. Manning, Z. Chen, M. Marquis, K.B. Averyt, M.Tignor and H.L. Mille) pp 996. Cambridge University Press, Cambridge and New York.

Keeley JE, Zedler PH (1998) Evolution of life histories in Pinus. In: Ecology and biogeography of Pinus. (ed Richardson DM) pp 219-248. Cambridge, Cambridge University Press.

Kelly AE, Goulden ML (2008) Rapid shifts in plant distribution with recent climate change. Proceedings of the National Academy of Sciences of the United States of America, 105, 11823-11826.

Kullman L (2002) Rapid recent range-margin rise of tree and shrub species in the Swedish Scandes. Journal of Ecology, 90, 68-77.

Lanner RM (1998) Seed dispersal in Pinus. In: Ecology and biogeography of Pinus. (ed Richardson DM) pp 281-295. Cambridge, Cambridge University Press.

Lloret F, Siscart D, Dalmases C (2004) Canopy recovery after drought dieback in holm-oak Mediterranean forests of Catalonia (NE Spain). Global Change Biology, 10, 20922099.

Lloyd AH (2005) Ecological histories from Alaskan tree lines provide insight into future change. Ecology, 86, 1687-1695.

Lorenz M (1995) International co-operative programme on assessment and monitoring of air pollution effects on forests - ICP forests. Water Air Soil Pollution, 85, 1221-1226.

Mayer H (1984) Wälder Europas, Stuttgart New York, Fischer.

McDowell N, Pockman WT, Allen CD et al. (2008) Mechanisms of plant survival and mortality during drought: why do some plants survive while others succumb to drought? New Phytologist, 178, 719-739.

McDowell NG (2011) Mechanisms linking drought, hydraulics, carbon metabolism, and vegetation mortality. New Phytologist, 155, 1051-1059

Meusel H (1992) Vergleichende Chorologie der zentraleuropäischen Flora III, Jena, Gustav Fischer.

Minerbi S (1993) Wie gesund sind unsere Wälder? 10. Bericht über den Zustand der Wälder im Südtirol. Assessorat für Forstwissenschaft der Autonomen Provinz Bozen.

Moser B, Temperli C, Schneiter G, Wohlgemuth T (2010) Potential shift in tree species composition after interaction of fire and drought in the Central Alps. European Journal of Forest Research, 129, 625-633.

Mueller RC, Scudder CM, Porter ME, Trotter RT, Gehring CA, Whitham TG (2005) Differential tree mortality in response to severe drought: evidence for long-term vegetation shifts. Journal of Ecology, 93, 1085-1093.

Oberhuber W (2001) The role of climate in the mortality of Scots pine (Pinus sylvestris L.) exposed to soil dryness. Dendrochronologia, 19, 45-55.

Oberhuber W, Stumbock M, Kofler W (1998) Climate tree-growth relationships of Scots pine stands (Pinus sylvestris L.) exposed to soil dryness. Trees - Structure and Function, 13, 19-27.

Oberhuber W, Swidrak I, Pirkebner D, Gruber A (2011) Temporal dynamics of nonstructural carbohydrates and xylem growth in Pinus sylvestris exposed to drought. Canadien Journal of Forest Research, 41, 1590-1597.

Ozenda P (1985) La végétation de la chaîne alpine. Paris, Masson. 
Penuelas J, Boada M (2003) A global change-induced biome shift in the Montseny mountains (NE Spain). Global Change Biology, 9, 131-140.

Penuelas J, Filella I (2001) Phenology - Responses to a warming world. Science, 294, 793795.

Pinheiro JC, Bates DM (2000) Mixed-effects models in S and S-PLUS. Springer, New York.

Polomski J, Schonfeld U, Braasch H, Dobbertin M, Burgermeister W, Rigling D (2006) Occurrence of Bursaphelenchus species in declining Pinus sylvestris in a dry Alpine valley in Switzerland. Forest Pathology, 36, 110-118.

R Development Core Team (2010) R: A language and environment for statistical computing. $R$ Foundation for Statistical Computing, Vienna, Austria. URL http://www.Rproject.org/

Rebetez M, Dobbertin M (2004) Climate change may already threaten Scots pine stands in the Swiss Alps. Theoretical and applied climatology, 79, 1-9.

Rigling A, Bräker O, Schneiter G, Schweingruber F (2002) Intra-annual tree-ring parameters indicating differences in drought stress of Pinus sylvestris forests within Erico-Pinion in Valais (Switzerland). Plant Ecology, 163, 105-121.

Rigling A, Brühlhart H, Bräker OU, Forster T, Schweingruber FH (2003) Effects of irrigation on diameter growth and vertical resin duct production in Pinus sylvestris L. on dry sites in the central Alps, Switzerland. Forest Ecology and Management, 175, 285-296.

Rigling A, Eilmann B, Koechli R, Dobbertin M (2010) Mistletoe-induced crown degradation in Scots pine in a xeric environment. Tree physiology, 30, 845-852.

Rigling A, Huber R, Bebi P, Brand F, Briner S, Buttler A, Elkin C, Gillet F, Grêt-Regamey A, Hirschi C, Lischke H, Scholz R, Seidl R, Spiegelberger T, Walz A, Zimmermann W, Bugmann H (2012) Sustainable land use in mountain regions under global change: synthesis across Scales and Disciplines. Ecology \& Society, in review.

Rigling A, Waldner PO, Forster T, Bräker OU, Pouttu A (2001) Ecological interpretation of tree-ring width and intraannual density fluctuations in Pinus sylvestris on dry sites in the central Alps and Siberia. Canadian Journal of Forest Research, 31, 18-31.

Rouault G, Candau JN, Lieutier F, Nageleisen LM, Martin JC, Warzee N (2006) Effects of drought and heat on forest insect populations in relation to the 2003 drought in Western Europe. Annals of Forest Science, 63, 613-624.

Schär C, Vidale PL, Luethi D, Frei C, Häberli C, Liniger MA, Appenzeller C (2004) The role in increasing temperature variability in European summer heatwaves. Nature, 427, 332-336.

Schilli S, Dobbertin M, Rigling A, Bucher H (2008) Waldföhrensterben um Chur und im Wallis. Bündnerwald 61, 70-74. .

Schmid E (1936) Die Reliktföhrenwälder der Alpen, Bern, Hans Huber.

Shiyatov SG (2003) Rates of change in the upper treeline ecotone in the Polar Ural mountains. Pages News, 11, 8-10.

Stauffer HB (2008) Contemporary Bayesian and frequentist statistical research methods for natural resource scientists. Wiley and Sons, Hoboken, New Jersey.

Thabeet A, Vennetier M, Gadbin-Henry C, Denelle N, Roux M, Caraglio Y, Vila B (2009) Response of Pinus sylvestris L. to recent climatic events in the French Mediterranean region. Trees-Structure and Function, 23, 843-853.

Thomas FM, Blank R, Hartmann G (2002) Abiotic and biotic factors and their interactions as causes of oak decline in Central Europe. Forest Pathology, 32, 277-307.

Turc L (1963) Evaluation des besoins en eau d'irrigation, évapotranspiration potentielle, formulation simplifié et mise à jour. Annales Agronomiques, 12, 13-49. 
Vachiano G, Garbarino M, Borgogno Mondino E, Motta R (2011) Evidences of drought stress as a predisposing factor to Scots pine decline in Valle d'Aosta (Italy). European Journal of Forest Resarch, 131, 989-1000.

Van Mantgem PJ, Stephenson NL, Byrne JC et al. (2009) Widespread increase of tree mortality rates in the western United States. Science, 323, 521-524.

Van der Burght L, Stoffel M, Bigler C (2012) Analysis and modelling of tree succession on a recent rockslide deposit. Plant Ecology, 213, 35-46.

Vertui F, Tagliaferro F (1998) Scots pine (Pinus sylvestris L.) die-back by unknown causes in the Aosta Valley, Italy. Chemosphere, 36, 1061-1065.

Vila-Cabrera A, Rodrigo A, Martinez-Vilalta J, Retana J (2012) Lack of regeneration and climatic vulnerability to fire of Scots pine may induce vegetation shifts at the southern edge of its distribution. Journal of Biogeography, 39, 488-496.

Walther G-R, Post E, Convey P et al. (2002) Ecological responses to recent climate change. Nature, 416, 289-359.

Weber P, Bugmann H, Fonti P, Rigling A (2008a) Using a retrospective dynamic competition index to reconstruct forest succession. Forest Ecology and Management 254, 96-106.

Weber P, Rigling A, Bugmann H (2008b) Sensitivity of stand dynamics to grazing in mixed Pinus sylvestris and Quercus pubescens forests: A modeling study. Ecological Modelling, 210, 301-311.

Weber P, Bugmann H, Rigling A (2007) Radial growth responses to drought of Pinus sylvestris and Quercus pubescens in an inner-Alpine dry valley. Journal of Vegetation Science, 18, 777-792.

Wermelinger B, Rigling A, Schneider Mathis D, Dobbertin M (2008) Assessing the role of bark- and wood-boring insects in the decline of Scots pine (Pinus silvestris) in the Swiss Rhone valley. Ecological Entomology 33, 239-249.

Wermelinger B, Seifert M (1999) Temperature-dependent reproduction of the spruce bark beetle Ips typographus, and analysis of the potential population growth. Ecological Entomology, 24, 103-110.

Zamora R, Gomez JM, Hodar JA, Castro J, Garcia D (2001) Effect of browsing by ungulates on sapling growth of Scots pine in a Mediterranean environment: consequences for forest regeneration. Forest Ecology and Management, 144, 33-42.

Zimmermann NE, Kienast F (1999) Predictive mapping of alpine grasslands in Switzerland: Species versus community approach. Journal of Vegetation Science, 10, 469-482.

Zuur A, Ieno EN, Walker N, Saveiliev AA, Smith GM (2009) Mixed effects models and extensions in ecology with $R$. Springer, New York.

Zweifel R, Bangerter S, Rigling A, Sterck F (2012) Pine and mistletoes - how to live with a leak in the water flow- and storage system? Experimental Botany, 63, 2565-2578.

Zweifel R, Rigling A, Dobbertin M (2009) Species-specific stomatal response of trees to drought - a link to vegetation dynamics? Journal of Vegetation Science, 20, 442-454.

Zweifel R, Steppe K, Sterck FJ (2007) Stomatal regulation by microclimate and tree water relations: interpreting ecophysiological field data with a hydraulic plant model. Journal of Experimental Botany, 58, 2113-2131.

Zweifel R, Zimmermann L, Newbery DM (2005) Modeling tree water deficit from microclimate: an approach to quantifying drought stress. Tree physiology, 25, 147156.

Zweifel R, Zimmermann L, Zeugin F, Newbery DM (2006) Intra-annual radial growth and water relations of trees: implications towards a growth mechanism. Journal of Experimental Botany, 57, 1445-1459. 


\section{Tables:}

Tab. 1: Occurrence of dead and living Scots pine and pubescent oak in the overstorey (1983/85 and 2002/03)

\begin{tabular}{|c|c|c|c|}
\hline & & Scots pine & pubescent oak \\
\hline $\begin{array}{l}\text { Plots with individuals in overstorey } \\
(1983 / 85) \text { out of } 186 \text { plots }\end{array}$ & [count] & 139 & 11 \\
\hline $\begin{array}{l}\text { Plots with individuals in overstorey } \\
(2002 / 03) \text { out of } 201 \text { plots }\end{array}$ & [count] & 153 & 19 \\
\hline $\begin{array}{l}\text { Individuals in overstorey } \\
(1983 / 85) \text { out of } 186 \text { plots }\end{array}$ & [count/ha] & 242.3 & 4.4 \\
\hline $\begin{array}{l}\text { Individuals in overstorey } \\
(2002 / 03) \text { out of } 201 \text { plots }\end{array}$ & [count/ha] & 200.0 & 11.3 \\
\hline Dead trees from $1983 / 85$ to $2002 / 03$ & [count/ha] & 33.2 & 0.4 \\
\hline $\begin{array}{l}\text { Dead and removed trees from } \\
1983 / 85 \text { to } 2002 / 03\end{array}$ & [count/ha] & 78.8 & 0.6 \\
\hline Mortality from $1983 / 85$ to $2002 / 03$ & {$[\%]$} & 13.7 & 8.6 \\
\hline $\begin{array}{l}\text { Mortality \& removal from } 1983 / 85 \\
\text { to } 2002 / 03\end{array}$ & {$[\%]$} & 32.5 & 14.8 \\
\hline $\begin{array}{l}\text { Change in number of individuals in } \\
\text { overstorey from } 1983 / 85 \text { to } 2002 / 03\end{array}$ & {$[\%]$} & -17.5 & 160.7 \\
\hline
\end{tabular}


Tab. 2: Model description of the best-fitting Scots pine mortality model (SMP10; see Table A in the Appendix). Survival probabilities were calculated for 985 Scots pine in 137 plots with a generalized linear mixed-effects model using a binomial distribution (eq. 1) and a logit-link function (eq. 2).

\begin{tabular}{lllll}
\hline \multicolumn{3}{c}{ Fixed effects: estimates \pm SE $(\mathrm{P})$} & & \multicolumn{2}{c}{$\begin{array}{l}\text { Random } \\
\text { effect: SE }\end{array}$} \\
\cline { 1 - 3 } Intercept & $\begin{array}{l}\text { Drought index } \\
(\mathrm{mm})\end{array}$ & $\begin{array}{l}\text { Stand basal area } \\
\left(\mathrm{m}^{2} \mathrm{ha}^{-1}\right)\end{array}$ & $\begin{array}{l}\mathrm{DBH} \\
(\mathrm{cm})\end{array}$ & Intercept \\
$\begin{array}{l}0.365 \pm 0.516 \\
(0.479)\end{array}$ & $\begin{array}{l}0.0015 \pm 0.0007 \\
(0.033)\end{array}$ & $\begin{array}{l}-0.037 \pm 0.017 \\
(0.032)\end{array}$ & $\begin{array}{l}0.058 \pm 0.009 \\
(<0.0001)\end{array}$ & 2.009 \\
\hline
\end{tabular}

Note: $\mathrm{SE}=$ standard error, $\mathrm{P}=\mathrm{P}$ value. Maximum likelihood estimation was used to fit the model.

Tab. 3: Occurrence of Scots pine and pubescent oak regeneration in relation to the overstorey $(\mathrm{n}=201$ plots $)$.

\begin{tabular}{|c|c|c|c|}
\hline & & Scots pine & pubescent oak \\
\hline Plots with regeneration & [count] & 34 & 67 \\
\hline Total regeneration & [count] & 486 & 2343 \\
\hline $\begin{array}{l}\text { Regeneration per ha } \\
\text { (only on plots with regeneration) }\end{array}$ & [count/ha] & 483.6 & 2331.3 \\
\hline \multirow{2}{*}{$\begin{array}{l}\text { Plots without regeneration but with individuals } \\
\text { in overstorey }\end{array}$} & [count] & 122 & 5 \\
\hline & {$[\%]$} & 80 & 26 \\
\hline \multirow{2}{*}{$\begin{array}{l}\text { Plots with regeneration and with individuals in } \\
\text { overstorey }\end{array}$} & [count] & 31 & 14 \\
\hline & {$[\%]$} & 20 & 74 \\
\hline \multirow{2}{*}{$\begin{array}{l}\text { Plots with regeneration but without individuals } \\
\text { in overstorey }\end{array}$} & [count] & 3 & 53 \\
\hline & [\%] & 8 & 79 \\
\hline
\end{tabular}


Tab. 4: Model description of the best-fitting regeneration models (Scots pine: RMP07; pubescent oak: RMO12; see Appendix Tab. B and C). The generalized linear models were fitted to 193 plots using a negative binomial distribution (eq. 3) and a log-link function (eq. 4).

\begin{tabular}{|c|c|c|c|c|c|c|c|c|}
\hline \multirow[t]{3}{*}{ Model } & \multicolumn{8}{|c|}{ Estimates $\pm \mathrm{SE}(\mathrm{P})$} \\
\hline & \multirow[b]{2}{*}{ Intercept } & \multirow[b]{2}{*}{$\begin{array}{l}\text { Drought index } \\
(\mathrm{mm})\end{array}$} & \multirow[b]{2}{*}{$\begin{array}{l}\text { Degree days } \\
\left({ }^{\circ} \mathrm{C}\right)\end{array}$} & \multicolumn{3}{|l|}{ Aspect } & \multirow[b]{2}{*}{$\begin{array}{l}\text { Slope } \\
(\%)\end{array}$} & \multirow[b]{2}{*}{$\begin{array}{l}\text { Dispersion } \\
\text { parameter }\end{array}$} \\
\hline & & & & East & South & West & & \\
\hline RMP07 & $\begin{array}{l}15.085 \pm 3.609 \\
(<0.0001)\end{array}$ & $\begin{array}{l}-0.0068 \pm 0.0016 \\
(<0.0001)\end{array}$ & $\begin{array}{l}-0.0039 \pm 0.0010 \\
(<0.001)\end{array}$ & & & & & $0.059 \pm 0.012$ \\
\hline RMO12 & $\begin{array}{l}-11.100 \pm 2.451 \\
(<0.0001)\end{array}$ & $\begin{array}{l}-0.0033 \pm 0.0011 \\
(0.003)\end{array}$ & $\begin{array}{l}0.0036 \pm 0.0007 \\
(<0.0001)\end{array}$ & $\begin{array}{l}4.463 \pm 0.676 \\
(<0.0001)\end{array}$ & $\begin{array}{l}4.561 \pm 0.660 \\
(<0.0001)\end{array}$ & $\begin{array}{l}1.335 \pm 0.619 \\
(0.031)\end{array}$ & $\begin{array}{l}0.0089 \pm 0.0103 \\
(0.390)\end{array}$ & $0.154 \pm 0.024$ \\
\hline
\end{tabular}

Note: $\mathrm{SE}=$ standard error, $\mathrm{P}=\mathrm{P}$ value. Models were fitted using maximum likelihood. For the variable aspect, north was set as reference level (i.e., the estimates for east, south and west are deviations from north).

\section{(C) 2012 Blackwell Publishing Ltd}




\section{Appendix:}

Table A: Model comparison of mortality models for Scots pine. Survival probabilities were calculated for 985 Scots pine in 137 plots with a generalized linear mixed-effects model using a binomial distribution (eq. 1) and a logit-link function (eq. 2).

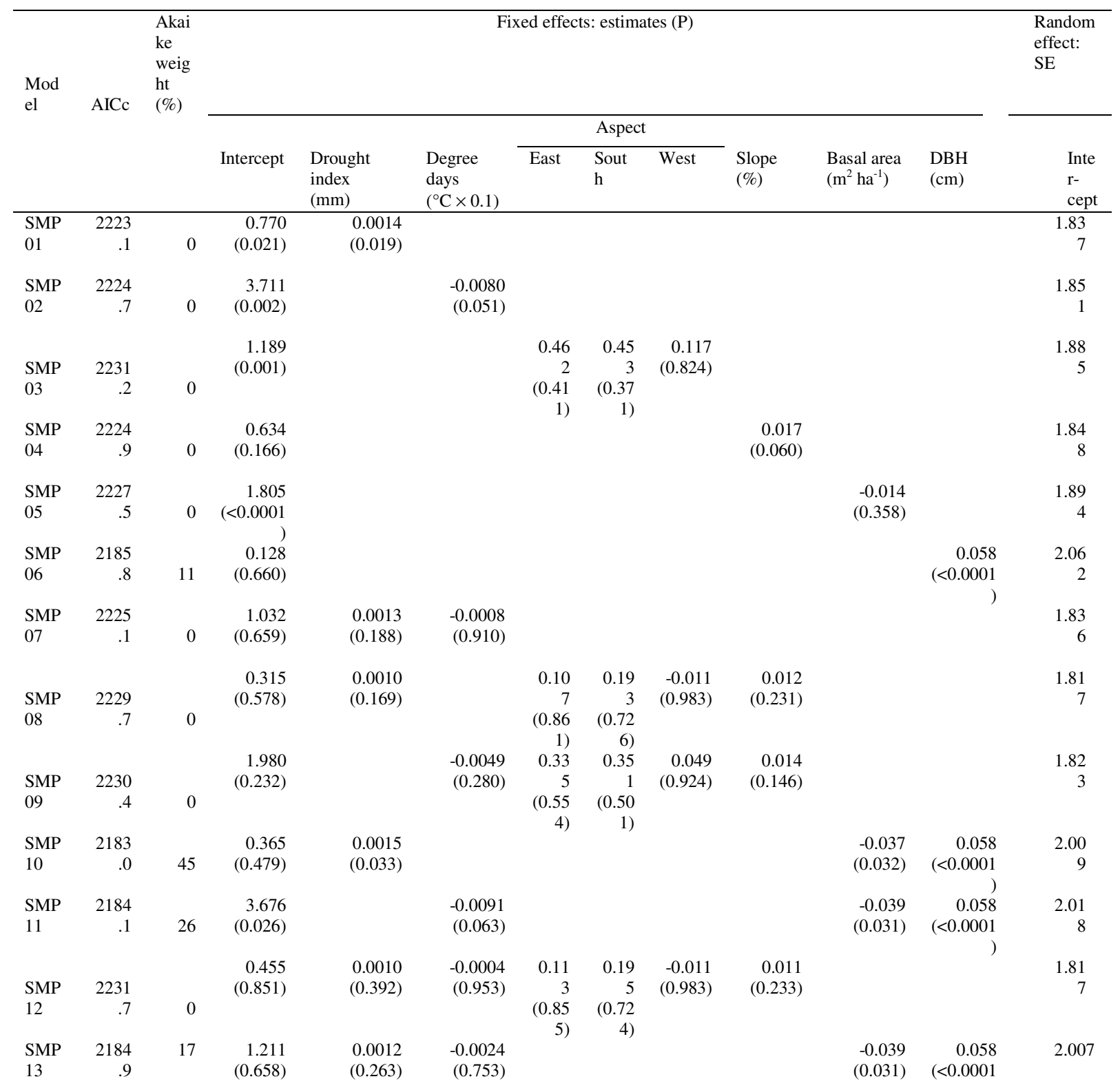




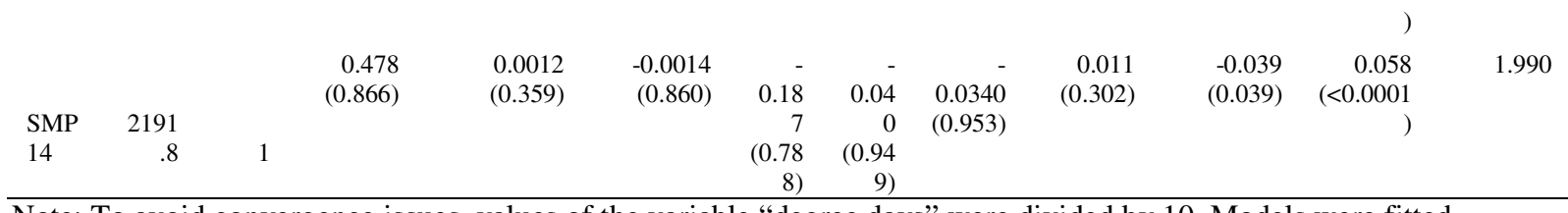

Note: To avoid convergence issues, values of the variable "degree days" were divided by 10. Models were fitted using maximum likelihood. For the variable aspect, north was set as reference level (i.e., the estimates for east, south and west are deviations from north).

$\mathrm{SE}=$ standard error, $\mathrm{P}=\mathrm{P}$ value, $\mathrm{AICc}=$ corrected Akaike Information Criterion .

Appendix: 
Table B: Model comparison of regeneration models for Scots pine. The generalized linear models were fitted to 193 plots using a negative binomial distribution (eq. 3) and a log-link function (eq. 4).

\begin{tabular}{|c|c|c|c|c|c|c|c|c|c|c|c|c|}
\hline \multirow{3}{*}{ Model } & \multirow{3}{*}{ AICc } & \multirow{3}{*}{$\begin{array}{l}\text { Akaike } \\
\text { weight } \\
(\%)\end{array}$} & \multicolumn{9}{|c|}{ Estimates (P) } & \multirow{3}{*}{$\begin{array}{l}\text { Dispersion } \\
\text { parameter } \pm \\
\text { approx. SE }\end{array}$} \\
\hline & & & \multirow[b]{2}{*}{ Intercept } & \multirow[b]{2}{*}{$\begin{array}{l}\text { Drought } \\
\text { index (mm) }\end{array}$} & \multirow[b]{2}{*}{$\begin{array}{l}\text { Degree days } \\
\left({ }^{\circ} \mathrm{C}\right)\end{array}$} & \multicolumn{3}{|c|}{ Aspect } & \multirow[b]{2}{*}{$\begin{array}{l}\text { Slope } \\
(\%)\end{array}$} & \multirow[b]{2}{*}{$\begin{array}{l}\text { Canopy } \\
\text { cover }(\%)\end{array}$} & \multirow[b]{2}{*}{$\begin{array}{l}\text { Bare soil } \\
(\%)\end{array}$} & \\
\hline & & & & & & East & South & West & & & & \\
\hline RMP01 & 403.4 & 2 & $\begin{array}{r}1.556 \\
(0.011)\end{array}$ & $\begin{array}{r}-0.0015 \\
(0.171)\end{array}$ & & & & & & & & $\begin{array}{r}0.050 \pm \\
0.010\end{array}$ \\
\hline RMP02 & 404.9 & 1 & $\begin{array}{r}1.395 \\
(0.497)\end{array}$ & & $\begin{array}{r}-0.0002 \\
(0.815)\end{array}$ & & & & & & & $\begin{array}{r}0.048 \pm \\
0.010\end{array}$ \\
\hline RMP03 & 401.7 & 4 & $\begin{array}{r}1.314 \\
(0.029)\end{array}$ & & & $\begin{array}{l}-1.958 \\
(0.034)\end{array}$ & $\begin{array}{r}0.195 \\
(0.816)\end{array}$ & $\begin{array}{r}1.650 \\
(0.058)\end{array}$ & & & & $\begin{array}{r}0.056 \pm \\
0.012\end{array}$ \\
\hline RMP04 & 404.0 & 1 & $\begin{array}{r}1.649 \\
(0.045)\end{array}$ & & & & & & $\begin{array}{r}-0.016 \\
(0.304)\end{array}$ & & & $\begin{array}{r}0.049 \pm \\
0.010\end{array}$ \\
\hline RMP05 & 401.7 & 4 & $\begin{array}{r}2.078 \\
(0.002)\end{array}$ & & & & & & & $\begin{array}{r}-0.022 \\
(0.026)\end{array}$ & & $\begin{array}{r}0.052 \pm \\
0.010\end{array}$ \\
\hline RMP06 & 404.3 & 1 & $\begin{array}{r}0.708 \\
(0.076)\end{array}$ & & & & & & & & $\begin{array}{r}0.0070 \\
(0.421)\end{array}$ & $\begin{array}{r}0.049 \pm \\
0.010\end{array}$ \\
\hline RMP07 & 396.4 & 52 & $\begin{array}{r}15.085 \\
(<0.0001)\end{array}$ & $\begin{array}{r}-0.0068 \\
(<0.0001)\end{array}$ & $\begin{array}{r}-0.0039 \\
(<0.001)\end{array}$ & & & & & & & $\begin{array}{r}0.059 \pm \\
0.012\end{array}$ \\
\hline RMP08 & 405.4 & 1 & $\begin{array}{r}1.377 \\
(0.135)\end{array}$ & $\begin{array}{r}-0.0013 \\
(0.292)\end{array}$ & & $\begin{array}{r}-1.106 \\
(0.262)\end{array}$ & $\begin{array}{r}0.685 \\
(0.456)\end{array}$ & $\begin{array}{l}-1.440 \\
(0.105)\end{array}$ & $\begin{array}{r}0.003 \\
(0.827)\end{array}$ & & & $\begin{array}{r}0.057 \pm \\
0.012\end{array}$ \\
\hline RMP09 & 404.7 & 1 & $\begin{array}{r}5.451 \\
(0.042)\end{array}$ & & $\begin{array}{r}-0.0010 \\
(0.159)\end{array}$ & $\begin{array}{l}-2.670 \\
(0.006)\end{array}$ & $\begin{array}{r}-0.459 \\
(0.602)\end{array}$ & $\begin{array}{l}-1.454 \\
(0.095)\end{array}$ & $\begin{array}{r}-0.019 \\
(0.211)\end{array}$ & & & $\begin{array}{r}0.057 \pm \\
0.012\end{array}$ \\
\hline RMP10 & 402.8 & 2 & $\begin{array}{r}2.922 \\
(<0.001)\end{array}$ & $\begin{array}{r}-0.0022 \\
(0.034)\end{array}$ & & & & & & $\begin{array}{l}-0.024 \\
(0.018)\end{array}$ & $\begin{array}{l}0.0060 \\
(0.471)\end{array}$ & $\begin{array}{r}0.055 \pm \\
0.011\end{array}$ \\
\hline RMP11 & 405.8 & 0 & $\begin{array}{r}1.382 \\
(0.505)\end{array}$ & & $\begin{array}{l}0.0002 \\
(0.719)\end{array}$ & & & & & $\begin{array}{l}-0.023 \\
(0.023)\end{array}$ & $\begin{array}{l}0.0009 \\
(0.917)\end{array}$ & $\begin{array}{r}0.052 \pm \\
0.010\end{array}$ \\
\hline RMP12 & 402.4 & 3 & $\begin{array}{r}12.046 \\
(<0.001)\end{array}$ & $\begin{array}{r}-0.0050 \\
(0.003)\end{array}$ & $\begin{array}{r}-0.0030 \\
(0.002)\end{array}$ & $\begin{array}{l}-0.861 \\
(0.378)\end{array}$ & $\begin{array}{r}0.332 \\
(0.710)\end{array}$ & $\begin{array}{r}-0.648 \\
(0.450)\end{array}$ & $\begin{array}{r}-0.009 \\
(0.553)\end{array}$ & & & $\begin{array}{r}0.063 \pm \\
0.013\end{array}$ \\
\hline '13 & 399.0 & 14 & $\begin{array}{r}14.116 \\
(<0.0001)\end{array}$ & $\begin{array}{r}-0.0064 \\
(<0.0001)\end{array}$ & $\begin{array}{r}-0.0034 \\
(0.001)\end{array}$ & & & & & $\begin{array}{l}-0.014 \\
(0.148)\end{array}$ & $\begin{array}{l}0.0018 \\
(0.821)\end{array}$ & $\begin{array}{r}0.061 \pm \\
0.013\end{array}$ \\
\hline RMP14 & 398.8 & 16 & $\begin{array}{r}9.733 \\
(0.005)\end{array}$ & $\begin{array}{r}-0.0033 \\
(0.041)\end{array}$ & $\begin{array}{r}-0.0018 \\
(0.064)\end{array}$ & $\begin{array}{r}1.707 \\
(0.081)\end{array}$ & $\begin{array}{r}0.198 \\
(0.820)\end{array}$ & $\begin{array}{l}-1.577 \\
(0.068)\end{array}$ & $\begin{array}{r}-0.025 \\
(0.115)\end{array}$ & $\begin{array}{r}-0.025 \\
(0.011)\end{array}$ & $\begin{array}{l}0.0130 \\
(0.100)\end{array}$ & $\begin{array}{r}0.073 \pm \\
0.016\end{array}$ \\
\hline
\end{tabular}

Jote: $\mathrm{SE}=$ standard error, $\mathrm{P}=\mathrm{P}$ value, AICc = corrected Akaike Information Criterion. Models were fitted using maximum likelihood. For the variable aspect, north was set as reference level (i.e., the estimates for east, south and west are deviations from north). Due to rounding errors, the values of the Akaike weights do not sum up to $100 \%$.

\section{(C) 2012 Blackwell Publishing Ltd}


Appendix:

Table C: Model comparison of regeneration models for pubescent oak. The generalized linear models were fitted to 193 plots using a negative binomial distribution (eq. 3) and a log-link function (eq. 4).

\begin{tabular}{|c|c|c|c|c|c|c|c|c|c|c|c|c|}
\hline \multirow{3}{*}{ Model } & \multirow{3}{*}{$\mathrm{AICc}$} & \multirow{3}{*}{$\begin{array}{l}\text { Akaike } \\
\text { weight } \\
\text { (\%) }\end{array}$} & \multicolumn{9}{|c|}{ Estimates (P) } & \multirow{3}{*}{$\begin{array}{l}\text { Dispersion } \\
\text { parameter } \pm \\
\text { approx. SE }\end{array}$} \\
\hline & & & \multirow[b]{2}{*}{ Intercept } & \multirow[b]{2}{*}{$\begin{array}{l}\text { Drought } \\
\text { index }(\mathrm{mm})\end{array}$} & \multirow[b]{2}{*}{$\begin{array}{l}\text { Degree days } \\
\left({ }^{\circ} \mathrm{C}\right)\end{array}$} & \multicolumn{3}{|c|}{ Aspect } & \multirow[b]{2}{*}{$\begin{array}{l}\text { Slope } \\
(\%)\end{array}$} & \multirow[b]{2}{*}{$\begin{array}{l}\text { Canopy } \\
\text { cover (\%) }\end{array}$} & \multirow[b]{2}{*}{$\begin{array}{l}\text { Bare soil } \\
(\%)\end{array}$} & \\
\hline & & & & & & East & South & West & & & & \\
\hline RMO01 & 745.4 & 0 & $\begin{array}{r}3.136 \\
(<0.0001)\end{array}$ & $\begin{array}{r}-0.0014 \\
(0.105)\end{array}$ & & & & & & & & $\begin{array}{r}0.079 \pm \\
0.011\end{array}$ \\
\hline RMO02 & 721.1 & 0 & $\begin{array}{r}-10.320 \\
(<0.0001)\end{array}$ & & $\begin{array}{r}0.0042 \\
(<0.0001)\end{array}$ & & & & & & & $\begin{array}{r}0.100 \pm \\
0.014\end{array}$ \\
\hline RMO03 & 730.9 & 0 & $\begin{array}{r}0.703 \\
(0.134)\end{array}$ & & & $\begin{array}{r}2.400 \\
(<0.001)\end{array}$ & $\begin{array}{r}2.424 \\
(<0.01)\end{array}$ & $\begin{array}{r}0.087 \\
(0.896)\end{array}$ & & & & $\begin{array}{r}0.095 \pm \\
0.014\end{array}$ \\
\hline RMO04 & 742.2 & 0 & $\begin{array}{r}1.523 \\
(0.017)\end{array}$ & & & & & & $\begin{array}{l}0.0168 \\
(0.150)\end{array}$ & & & $\begin{array}{r}0.081 \pm \\
0.012\end{array}$ \\
\hline RMO05 & 736.8 & 0 & $\begin{array}{r}0.513 \\
(0.328)\end{array}$ & & & & & & & $\begin{array}{r}0.028 \\
(<0.001)\end{array}$ & & $\begin{array}{r}0.086 \pm \\
0.012\end{array}$ \\
\hline RMO06 & 741.6 & 0 & $\begin{array}{r}2.775 \\
(<0.0001)\end{array}$ & & & & & & & & $\begin{array}{r}-0.0165 \\
(0.014)\end{array}$ & $\begin{array}{r}0.082 \pm \\
0.012\end{array}$ \\
\hline RMO07 & 722.0 & 0 & $\begin{array}{r}-12.739 \\
(<0.0001)\end{array}$ & $\begin{array}{l}0.0016 \\
(0.145)\end{array}$ & $\begin{array}{r}0.0047 \\
(<0.0001)\end{array}$ & & & & & & & $\begin{array}{r}0.101 \pm \\
0.015\end{array}$ \\
\hline RMO08 & 706.3 & 0 & $\begin{array}{r}0.546 \\
(0.408)\end{array}$ & $\begin{array}{r}-0.0066 \\
(<0.0001)\end{array}$ & & $\begin{array}{r}4.243 \\
(<0.0001)\end{array}$ & $\begin{array}{r}3.924 \\
(<0.0001)\end{array}$ & $\begin{array}{r}1.278 \\
(0.045)\end{array}$ & $\begin{array}{l}0.0305 \\
(0.006)\end{array}$ & & & $\begin{array}{r}0.127 \pm \\
0.019\end{array}$ \\
\hline RMO09 & 690.6 & 16 & $\begin{array}{r}-14.930 \\
(<0.0001)\end{array}$ & & $\begin{array}{r}0.0047 \\
(<0.0001)\end{array}$ & $\begin{array}{r}3.529 \\
(<0.0001)\end{array}$ & $\begin{array}{r}3.824 \\
(<0.0001)\end{array}$ & $\begin{array}{r}1.081 \\
(0.081)\end{array}$ & $\begin{array}{r}-0.0013 \\
(0.896)\end{array}$ & & & $\begin{array}{r}0.147 \pm \\
0.022\end{array}$ \\
\hline RMO10 & 736.1 & 0 & $\begin{array}{r}1.944 \\
(0.004)\end{array}$ & $\begin{array}{r}-0.0027 \\
(<0.001)\end{array}$ & & & & & & $\begin{array}{r}0.029 \\
(<0.001)\end{array}$ & $\begin{array}{r}-0.0107 \\
(0.102)\end{array}$ & $\begin{array}{r}0.090 \pm \\
0.013\end{array}$ \\
\hline RMO11 & 720.2 & 0 & $\begin{array}{r}-10.170 \\
(<0.0001)\end{array}$ & & $\begin{array}{r}0.0037 \\
(<0.0001)\end{array}$ & & & & & $\begin{array}{r}0.018 \\
(0.014)\end{array}$ & $\begin{array}{r}-0.0031 \\
(0.622)\end{array}$ & $\begin{array}{r}0.015 \pm \\
0.015\end{array}$ \\
\hline RMO12 & 687.3 & 84 & $\begin{array}{r}-11.100 \\
(<0.0001)\end{array}$ & $\begin{array}{r}-0.0033 \\
(0.003)\end{array}$ & $\begin{array}{r}0.0036 \\
(<0.0001)\end{array}$ & $\begin{array}{r}4.463 \\
(<0.0001)\end{array}$ & $\begin{array}{r}4.561 \\
(<0.0001)\end{array}$ & $\begin{array}{r}1.335 \\
(0.031)\end{array}$ & $\begin{array}{l}0.0089 \\
(0.390)\end{array}$ & & & $\begin{array}{r}0.154 \pm \\
0.024\end{array}$ \\
\hline$J 13$ & 722.1 & 0 & $\begin{array}{r}-11.410 \\
(<0.0001)\end{array}$ & $\begin{array}{l}0.0007 \\
(0.501)\end{array}$ & $\begin{array}{r}0.0040 \\
(<0.0001)\end{array}$ & & & & & $\begin{array}{r}0.017 \\
(0.022)\end{array}$ & $\begin{array}{r}-0.0021 \\
(0.740)\end{array}$ & $\begin{array}{r}0.105 \pm \\
0.015\end{array}$ \\
\hline
\end{tabular}

Vote: $\mathrm{SE}=$ standard error, $\mathrm{P}=\mathrm{P}$ value. Models were fitted using maximum likelihood. $\ddagger$ Model RMO014 did not converge. For the variable aspect, north was set as reference level (i.e., the estimates for east, south and west are deviations from north).

\section{(C) 2012 Blackwell Publishing Ltd}




\section{Figure legends:}

Fig. 1: a) Map of the study area Valais including the four weather stations Bex, Martigny, Sion and Visp. The long-term monitoring plot is located in Visp. b) Variability of monthly precipitation over the year (period 1961-1990) for the four weather stations within the study area.

Fig. 2: Spatial distribution of Scots pine and pubescent oak individuals in the overstorey (number of trees per $500 \mathrm{~m}^{2}$ ) and in the regeneration (number of saplings per $50 \mathrm{~m}^{2}$ ); observations from 2002/03 (C 2005 BFS GEOSTAT/swisstopo).

Fig. 3: a) Longitudinal-latitudinal distribution and b) boxplots of the altitudinal distribution of Scots pine mortality including tree removal for the period from $1983 / 85$ to $2002 / 03$. Only plots with at least 5 trees present in the overstorey during the first survey were considered. The vertical grey bar represents the Swiss average (@ 2005 BFS GEOSTAT/swisstopo)

Fig. 4: Temporal variability in drought (drought index calculated for April to August, blue line) and Scots pine mortality (current August to August in the following year, red line) surveyed on the long-monitoring plot Visp. Note the inverse scale for the drought index.

Fig. 5: Total number of saplings found on all sites (grey bars) and the percentage of browsing damage (black bars) of Scots pine and pubescent oak compared to different tree and shrub species (observations from 2002/03). 


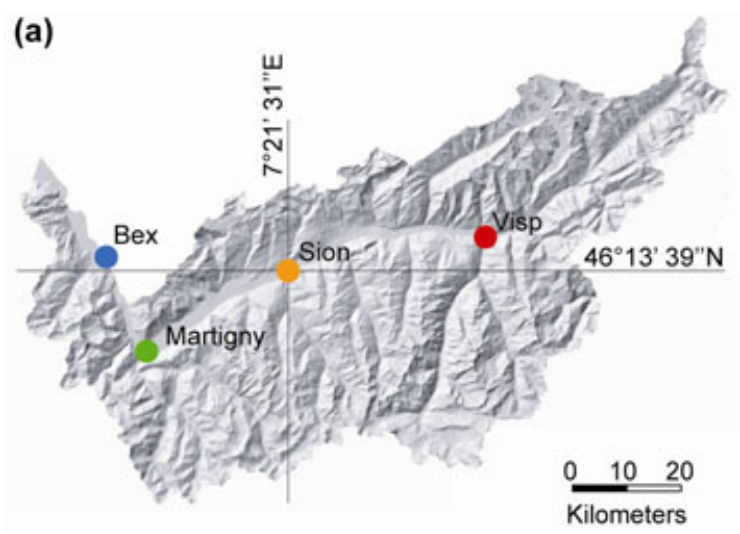

(b)
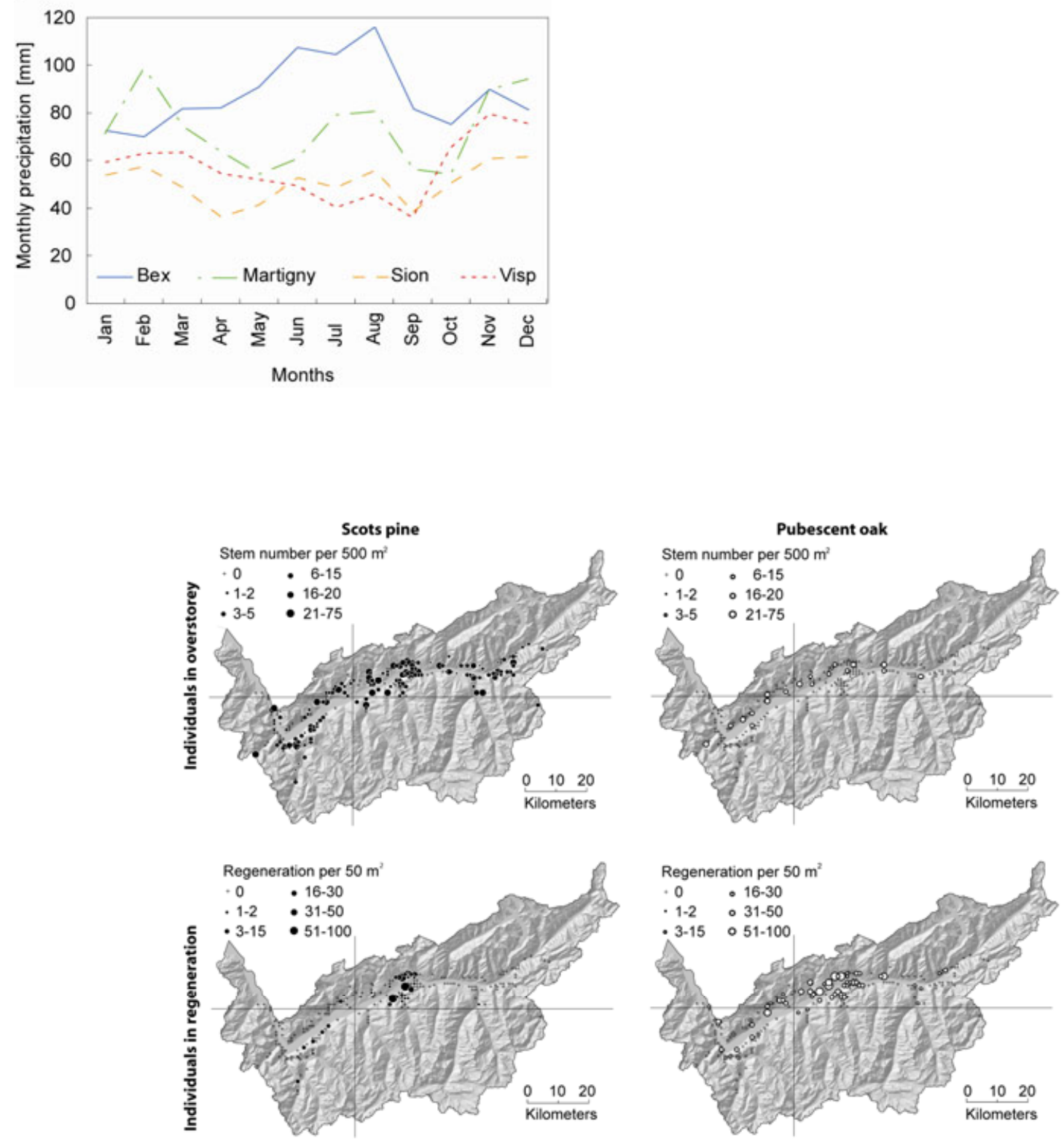

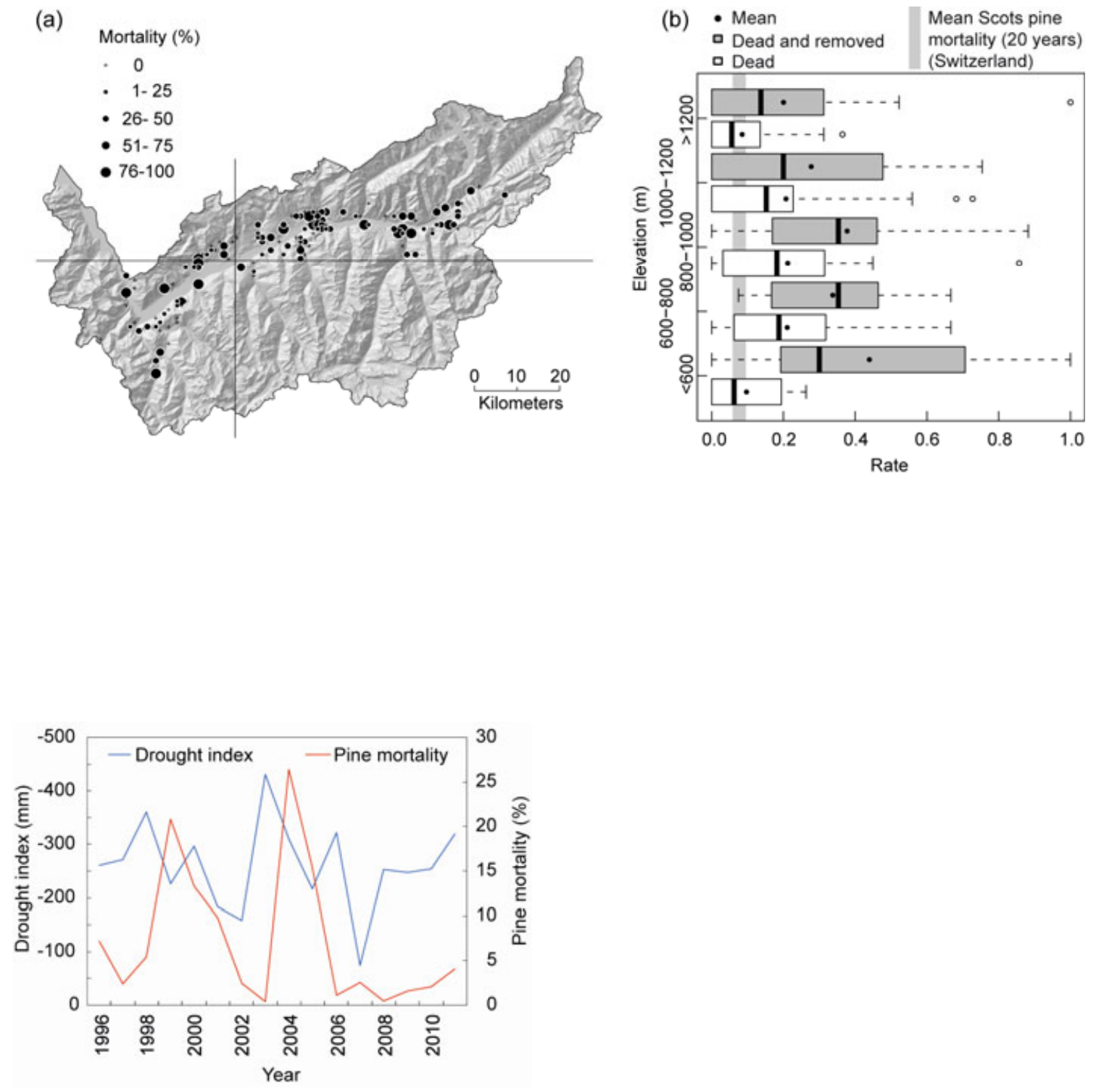


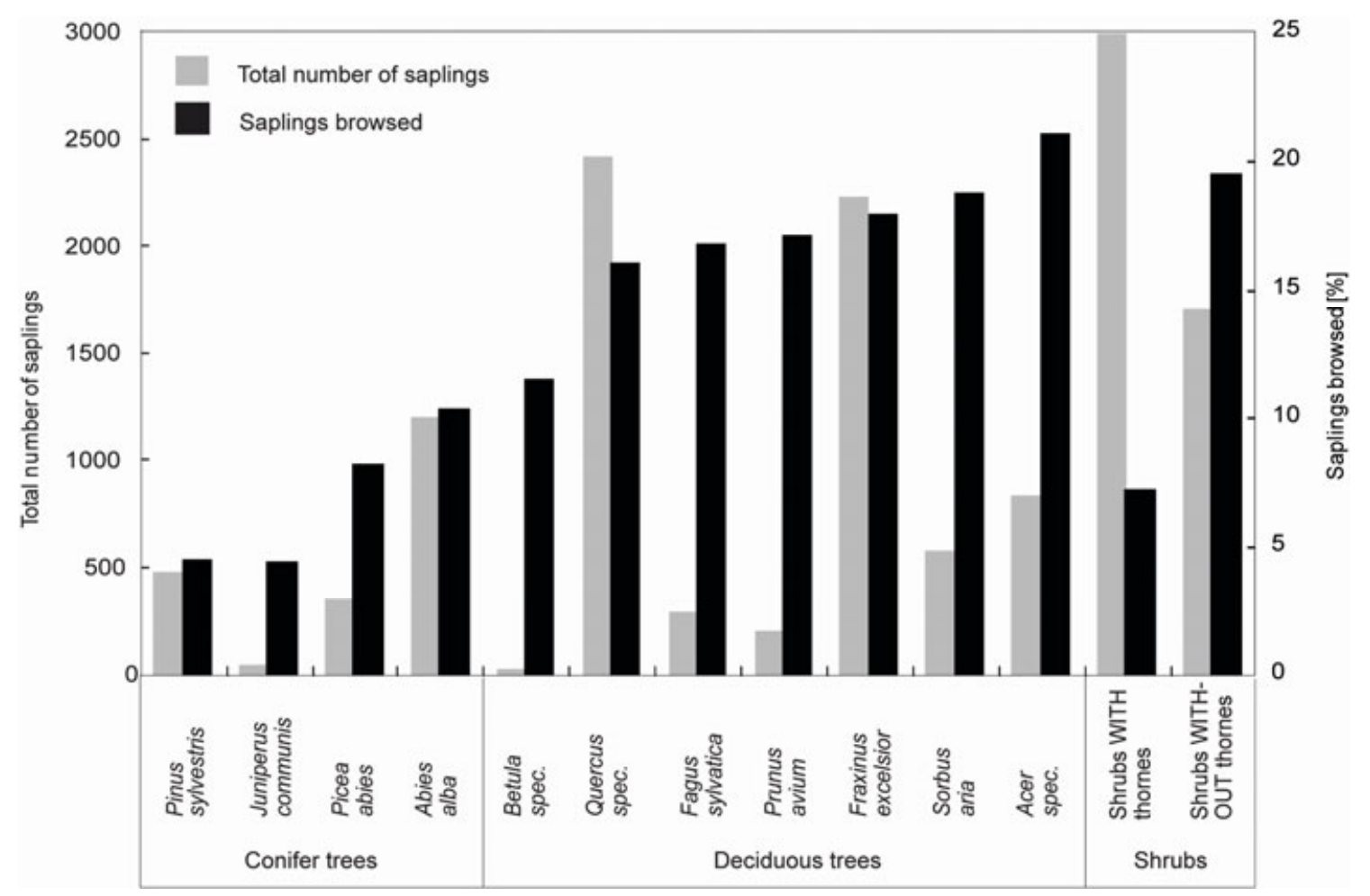

